\title{
Interactive Teaching Mode of Biology course under the New Media Technology
}

\author{
Kai Song ${ }^{1, a}$, Mei Bie ${ }^{2, b}$, Jian Zhang ${ }^{3, c}$, and Anhua Meng ${ }^{4, d}$ \\ ${ }^{1}$ School of Life Science, Changchun Normal University, Jilin Province, P.R.China \\ ${ }^{2}$ Institute of Media and Communications, Changchun Normal University, Jilin Province, P.R.China \\ ${ }^{3}$ Center for Faculty Development, Northeast Normal University, Jilin Province, P.R.China \\ ${ }^{4}$ High School Attached to Northeast Normal University, Jilin Province, P.R.China

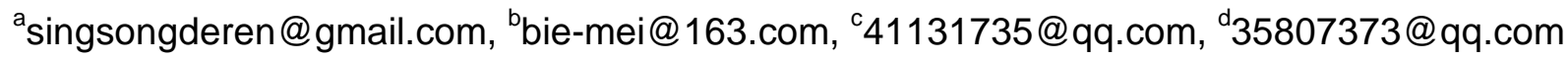

Keywords: Interactive Teaching Mode; Higher School Education; New Media; Biology

Abstract. Compared with the traditional teaching methods, modern new media including the instructional and social media represent the new direction for the mode of education and teaching quietly, which contributes to the effectiveness of teaching increasingly. Interactive teaching mode at biological teaching of college is useful at least three ways: closely linked to the teaching import, experimental demonstration and information supplement. A survey about the interactive teaching mode under the new media technology has been carried out in the first half of 2015 . The second grade undergraduate major in biology of Changchun Normal University are involved in our questionnaire and interview. Most of the students (77.95 percent) would like that the interactive teaching mode is introduced to their biology class.

\section{Introduction}

New media is emerging as a media transfer mode, as opposed to traditional media. The new media forms of newspapers, radio, television and other traditional media, are the use of digital technology, network technology, mobile technology, through the Internet, wireless communications networks, cable networks and other channels as well as computers, mobile phones, digital televisions and other terminal, to provide users with information and entertainment media communication pattern and form. The features of new media are interactive and instant, massive and sharing, multimedia and hypertext, personalization and community-oriented. [1]

The optimization and improvement of teaching methods to enhance the effectiveness of teaching are playing an increasingly important role at the biology teaching of the university. Compared with the traditional teaching methods, modern new media including the instructional and social media represent the new direction for the mode of education and teaching quietly, which contributes to the effectiveness of teaching increasingly. The important role of new media in high school biology teaching and its effective integration into the biology teaching activities needs to be viewed in perspective by the college biology teacher.

\section{Interactive teaching mode in promoting the biological teaching}

Interactive teaching mode at biological teaching of college is useful at least three ways: closely linked to the teaching import, experimental demonstration and information supplement.

Closely linked to the teaching import. Among the teaching practice, the teaching import as the important part of the instruction to stimulate students' enthusiasm has not been paid attention properly by the college teachers. This part is used properly which can effectively stimulate students' interest in learning, and lay a good foundation for the whole teaching activities. [2] Biology as an esoteric discipline, the oral teaching mode often appears to be inadequate. In this regard, the interactive and vivid media means should be carried out effectively to enhance the students' interest in learning. For 
example, instead of the oral description, the multimedia presentation could combine the biotechnology research with the life stories to allow students access to more information on biotechnology.

Experimental demonstration. Experimental instruction of biology with the interactive media could display the procedure and the results of the experiment visually, so that it is easier for students to learn these experimental research techniques which are difficult to carry out as limited conditions. [3]For example, a variety of teaching and demonstrate methods of microscope; observing the sheet of cytology and histopathology; culture technology of cell; micro-manipulation techniques; live cell culture technology; electric power through fusion technology. It is easier for students to learn the biological experimental technologies by interactive teaching methods, thus the learning activities full of attraction. Fig. 1 is the live video broadcast operation flowchart, laboratory of cell biology.

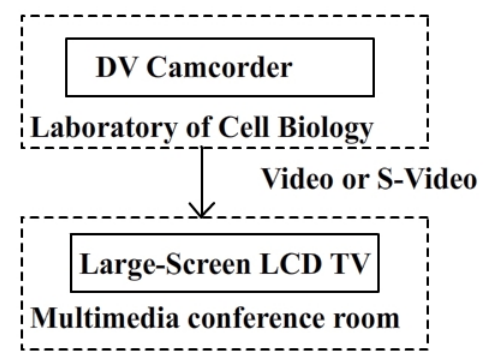

Fig. 1 Laboratory of Cell Biology, live video broadcast operation flowchart

Information supplement. The use of social media information means to broaden the teaching information of biological sources, enhance teacher-student interaction. Wechat, microblog represent the open and interactive new media which allows the college students and teachers become the disseminators of information. Modern society is an information world; teachers can obtain information through traditional forms of media, but also by the tablet PCs, mobile phones and other devices to break through the limitations of the classroom. [4] At the same time, learners are grouped together to be a learning community outside the classroom, so that students could catch the general ideas of the instructional content before class, keep the after-school reinforce learning, and communicate with teachers and learning companions. All of these activities are good for the transformation of tacit knowledge into explicit knowledge.

\section{Case study---- the application of interactive teaching mode under the new media technology}

\section{Application Environment}

a) Formal lass teaching. Teachers should download the required media resources from the resource modules for the formal classroom teaching, so that the abstract biological knowledge is changed to visual images which are easier for the students to follow.

b) Independent learning. Learners could use this resource platform with systematized knowledge system, comprehensive key points, to do the independent learning, preview, review after class via network. [5]

Practice Environment. In this study, all the factors are considered, the second grade undergraduate major in biology of Changchun Normal University were chosen as research objects. Interactive teaching resource is genetic basis part of the basic biology courses, including classroom teaching in the virtual model of the DNA molecule, the formation of the molecular structure of DNA, DNA molecule semi-conservative replication process.

Student Interview. We tried to understand the teaching effect by interviews with the students. The dialogue is from the following aspects:

a) Compared with conventional teaching methods, interactive teaching mode under the new media applications, what is the difference, how about the experience of the students. 
b) Whether the students still use the teaching resources out-of-class? $\square$ The satisfaction of the instructional design under the new media technology.

c) Whether the resources run convenience?

d) How about the personal feelings of student about the interactive teaching resources and the new media technology?

For these problems, we summed up the following points by talking with students:

a) The biological interactive teaching resources are inadequate relatively. [6] Most of the instructional contents are shown in the form of text and pictures. The students try to understand the knowledge by the oral presentations of teachers or their own understanding.

b) The test was carried out in two classes, with a total number of 68 . According to the conversation, it is much easier to know the DNA molecular structure for the student by using the interactive resources, which improve the effectiveness of teaching. The students did not have any contact with a similar model structure before, so they are interested in this practice.

c) The students are satisfied with the interactive teaching resource, since it is easy to use, no separate installation of plug-ins required, good for the after-school review.

Questionnaire. The questionnaire forms for the experimental class students were investigated after the test. The sample of the questionnaire consisted of 92 students. Some representation results of the questionnaire are as follows. (Note: Since this is an artificial statistical questionnaire, so the percentage of the decimal point is rounded off) The first part of our investigation is the acceptance of the interactive teaching mode for the students, and some of the findings are shown as Table $\mathbf{1}$.

\begin{tabular}{|l|l|l|l|l|}
\hline $\begin{array}{l}\text { Understand the biological structures or the } \\
\text { phenomenon }\end{array}$ & $\begin{array}{l}\text { Could } \\
\text { understand } \\
29.4 \%\end{array}$ & $\begin{array}{l}\text { Feel } \\
\text { difficult } \\
54.4 \%\end{array}$ & \multicolumn{2}{|l|}{$\begin{array}{l}\text { Could not understand } \\
16.2 \%\end{array}$} \\
\hline Be interested in the interactive teaching mode & $\begin{array}{l}\text { Very } \\
\text { interested } \\
17.6 \%\end{array}$ & $\begin{array}{l}\text { Interested } \\
51.5 \%\end{array}$ & $\begin{array}{l}\text { In } \\
\text { general } \\
25 \%\end{array}$ & $\begin{array}{l}\text { Not } \\
\text { interested } \\
5.9 \%\end{array}$ \\
\hline $\begin{array}{l}\text { Whether the interactive teaching mode could } \\
\text { make the learning process easy and enjoyable? }\end{array}$ & $\begin{array}{l}\text { Yes } \\
60.3 \%\end{array}$ & $\begin{array}{l}\text { No } \\
17.6 \%\end{array}$ & $\begin{array}{l}\text { Other } \\
22.1 \%\end{array}$ \\
\hline
\end{tabular}

Table 1. Areas of the teachers from

Do you think the interactive resources will help your own learning? The answers are shown as Fig 2.

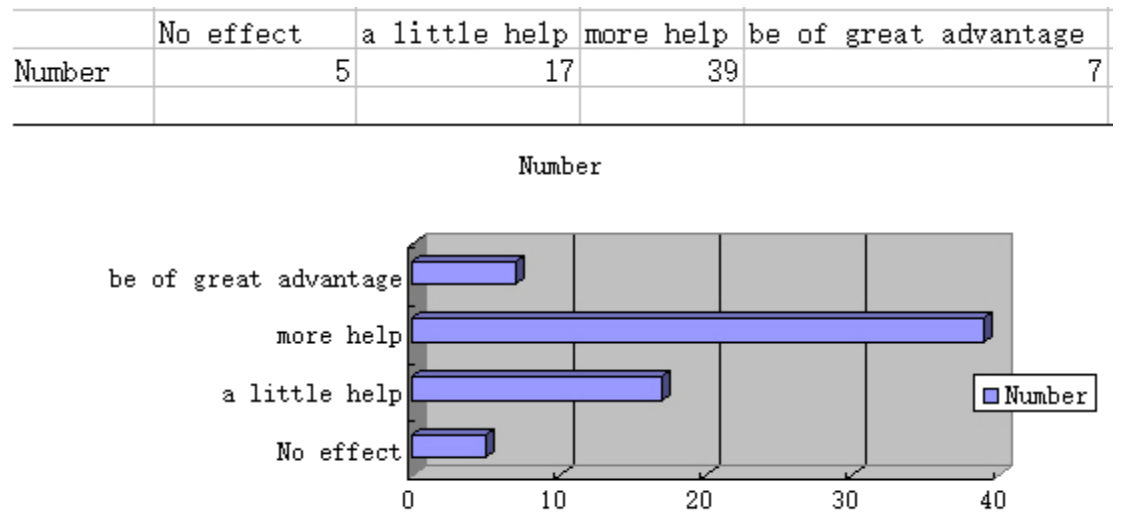

Fig 2. Answers of the question whether interactive resources will help your own learning 
The answers of whether you would like the interactive teaching mode is introduced in the biological teaching in the future? are: "I really hope so" 13.24 percent; "I hope" 64.71 percent; "do not matter" 20.59 percent; "I do not want" 1.47 percent;

The survey data of these questions above indicate that nearly half of the students feel difficult to understand the complex biological phenomena and results. Most of the students (57.35 percent) believe the introduction of the interactive resources will be of great benefit their learning. 77.95 percent students would like the interactive teaching mode is introduced in their biology class. Some students gave us their suggestion about the interactive resource, such as they would like the type size increased, and the font colors should be colorful or customized.

\section{Summary}

The central role of teachers. Because of the interactive new media teaching model has the characteristics of flexibility, in other words there is no unified model. [7] Not only in the classroom teacher design student activities in a reasonable manner guidance, to achieve optimization of classroom teaching, also changing teaching methods according to the students' change. The teacher guide students to carry out timely discussions, and take the whole situation into account, in order to fully play the guiding role. [8] Teachers can change or set parameters based on the student's personality development and acceptance, in terms of teaching content, teaching episode, and the progress. The classroom is full of exploration and research.

Encourage individuality and practical innovation of the students. There are two parts should be paid attention to for the teachers who carry out the interactive teaching mode under the new media technology. On the one hand, it is the instructional design for the knowledge learning. On the other hand, that is the self-confidence, lively character and the team spirit of the students. [9]

\section{Acknowledgements}

This work was financially supported by Jilin Philosophy and Social Science Foundation (2015BS27), Jilin Educational Scientific Research Leading Group (GH14359), and Changchun Normal University under Contract No. [2011]009.

\section{References}

[1] X. Su, in: The Science Education Article Collects. Vol. 2 (2014), p. 182-183

[2] Y. Y. Li, in: Middle School Biology. Vol.6(2009), p. 29-31

[3] X. R. Cao and S. Y. Gu, in Northwest Medical Education. Vol.3 (2013), p. 524-527

[4] D. Chen: submitted to Central China Normal University(2012)

[5] Y. M. Dai, in: The creation and realization of biology teaching resources based on Flash 3D in middle school. p. 43-47

[6] X. J. Du, in: Journal of Educational Institute of Jilin Province. Vol.31(2015), p. 77-80

[7] X. Y. Lou: submitted to Chongqing Normal University(2015)

[8] S. M. Jia, in: Teacher's Education. Vol.12 (2014), p. 26-28

[9] Information on http:// www.jyb.cn/high/sjts/201401/t20140117_567594.html 